\title{
Maxillary protraction and vertical control utilizing skeletal anchorage for midfacial-maxillary deficiency
}

\author{
Kensuke MATSUMOTO ${ }^{1} \bowtie$ \\ (i) https://orcid.org/0000-0002-2885-1793 \\ Nipul TANNA ${ }^{2}$ \\ (D) https://orcid.org/0000-0002-4741-9728
}

Submitted: April 13, 2020 - Revised and accepted: September 24, 2020 凶mensuke@upenn.edu

(1) University of Pennsylvania, School of Dental Medicine, Department of Periodontics and Orthodontics (Philadelphia/PA, USA).

(2) University of Pennsylvania, School of Dental Medicine, Department of Orthodontics (Philadelphia/PA, USA). 


\section{ABSTRACT}

Introduction: The efficacy and efficiency of early treatment of skeletal Class III patients with facemask therapy are well-documented; however, very few cases for adolescents or adults were reported. Objective: The aim of this case report was to demonstrate skeletal and dental correction of a post-pubertal-growth-spurt patient whose malocclusion consisted of a skeletal Class III with slight transverse deficiency, a high mandibular plane angle, and a retrusive maxillary complex. Case report: A 13-year-5-months old Hispanic female was diagnosed as a retrognathic maxilla and mandible, a high mandibular plane angle, open bite pattern, a bilateral Angle Class I molar relationship with an anterior crossbite on the maxillary lateral incisors. A TAD-supported Haas rapid palatal expander was utilized for maxillary protraction combined with a facemask, vertical control, and maxillary molar distalization with fixed appliance. Results: The total treatment time was 26 months. An improved facial profile with maxillarylip support and more prominent cheeks was established. Adequate vertical control prevented a change in the mandibular plane angle even though facemask treatment can increase the vertical dimension. After the 18-month retention, excellent stability of the treatment results was shown. Conclusion: With skeletal anchorage and facemask treatment, orthodontists have the ability of expanding and protracting the maxilla without tipping maxillary molars buccally and without the risk of unfavorable periodontal consequences. A TAD-supported Haas rapid palatal expander allowed to control the vertical dimension and distalize molars, while minimizing undesired consequences.

Keywords: TADs. Palatal expander. Facemask. Class III correction. Skeletal anchorage. 


\section{RESUMO}

Introdução: A eficácia e a eficiência do tratamento precoce de pacientes Classe III esquelética usando máscara facial são bem documentadas na literatura. Entretanto, poucos casos de adolescentes ou adultos foram descritos. Objetivo: O objetivo do presente relato de caso foi demonstrar as correções esqueléticas e dentárias em uma paciente pós-surto de crescimento puberal, cuja má oclusão consistia de uma Classe III esquelética com deficiência transversa suave, plano do ângulo mandibular aumentado e complexo maxilar retruído. Relato de caso: Uma paciente hispânica, com treze anos e cinco meses de idade, foi diagnosticada com retrusão maxilomandibular, ângulo do plano mandibular aumentado, padrão de mordida aberta, relação bilateral de molares em Classe I e mordida cruzada nos incisivos laterais superiores. Um aparelho de Haas suportado por dispositivos de ancoragem temporária (DATs) foi usado para a protração maxilar, combinado com máscara facial, controle vertical e distalização de molares superiores com aparelho fixo. Resultados: O tempo total de tratamento foi de 26 meses. Houve melhora no perfil facial, com aumento no suporte labial e bochechas mais proeminentes. O controle vertical adequado evitou uma mudança no plano do ângulo mandibular, apesar de o tratamento com máscara facial poder aumentar a dimensão vertical. Após contenção por 18 meses, uma excelente estabilidade do tratamento foi observada. Conclusão: Com a ancoragem esquelética e o tratamento com máscara facial, os ortodontistas têm a possibilidade de expandir e protrair a maxila sem a inclinação vestibular dos molares superiores e sem o risco de consequências periodontais desfavoráveis. Um expansor de Haas suportado por DATs permitiu o controle da dimensão vertical e distalização dos molares, com redução de consequências indesejáveis.

Palavras-chave: DATs. Expansor palatino. Máscara facial. Correção de Classe III. Ancoragem esquelética. 


\section{INTRODUCTION}

The efficacy and efficiency of skeletal Class III patients in early treatment are well-documented. Maxillary deficiency is often treated with maxillary protraction, and may be with or without palatal expansion. Treatment should be carried out in patients less than 10 years of age to enhance the orthopedic effect. ${ }^{1,2}$ However, there are some reports in the literature that there is no statistically significant difference between younger and older (> 10-year-old) children.-6 Discrepancy between the skeletal and chronological ages may be a factor, and it might be better to consider the skeletal age as a clinical indicator to determine the effectiveness of using a facemask. ${ }^{7}$ However, even if correction can be achieved in all growing patients, the skeletal changes may be smaller in older children. This case report demonstrates the efficacy of a TAD-supported Haas rapid palatal expander in conjunction with a facemask utilized for transverse correction, sagittal correction, and vertical control.

\section{DIAGNOSIS AND ETIOLOGY}

A 13-year-5-months old Hispanic female presented with the following chief complaint: "I don't like my front teeth, which are not straight". Her medical history was noncontributory, and she was in post menarche. She had routine hygiene visits every six months and was stable from periodontal and restorative perspectives. Her oral hygiene was fair. 
Her nasal dorsum was deviated slightly toward the right side (Figs 1A-I). She had a straight profile, with a dolichocephalic facial-type, an obtuse nasolabial angle, a retrusive upper lip, and a flat chin. Facial thirds were well balanced. Her cheeks were flattened, and the maxillary complex appeared retrusive. She had a symmetrical face and competent lips at rest, with a thin upper lip. The smile arc was inconsonant, with a $90 \%$ incisor display.

Intraorally, she had bilateral Angle Class I molar relationships, with an anterior crossbite on the maxillary lateral incisors (Figs 1J-O). The left maxillary canine was insufficiently erupted. Her maxillary molars were buccally inclined, and mandibular molars were lingually inclined. After correcting their inclinations, molar relationships would be of bilateral crossbite. Therefore, her transverse skeletal diagnosis was of maxillary transverse deficiency. Her maxillary and mandibular midlines were deviated $1 \mathrm{~mm}$ toward the left, with an overjet of $1.6 \mathrm{~mm}$ and overbite of $0.5 \mathrm{~mm}$. There was crowding of $5 \mathrm{~mm}$ in the maxillary arch and $5 \mathrm{~mm}$ in the mandibular arch. Pretreatment panoramic radiograph showed partial development of all third molars (Fig 1P). 

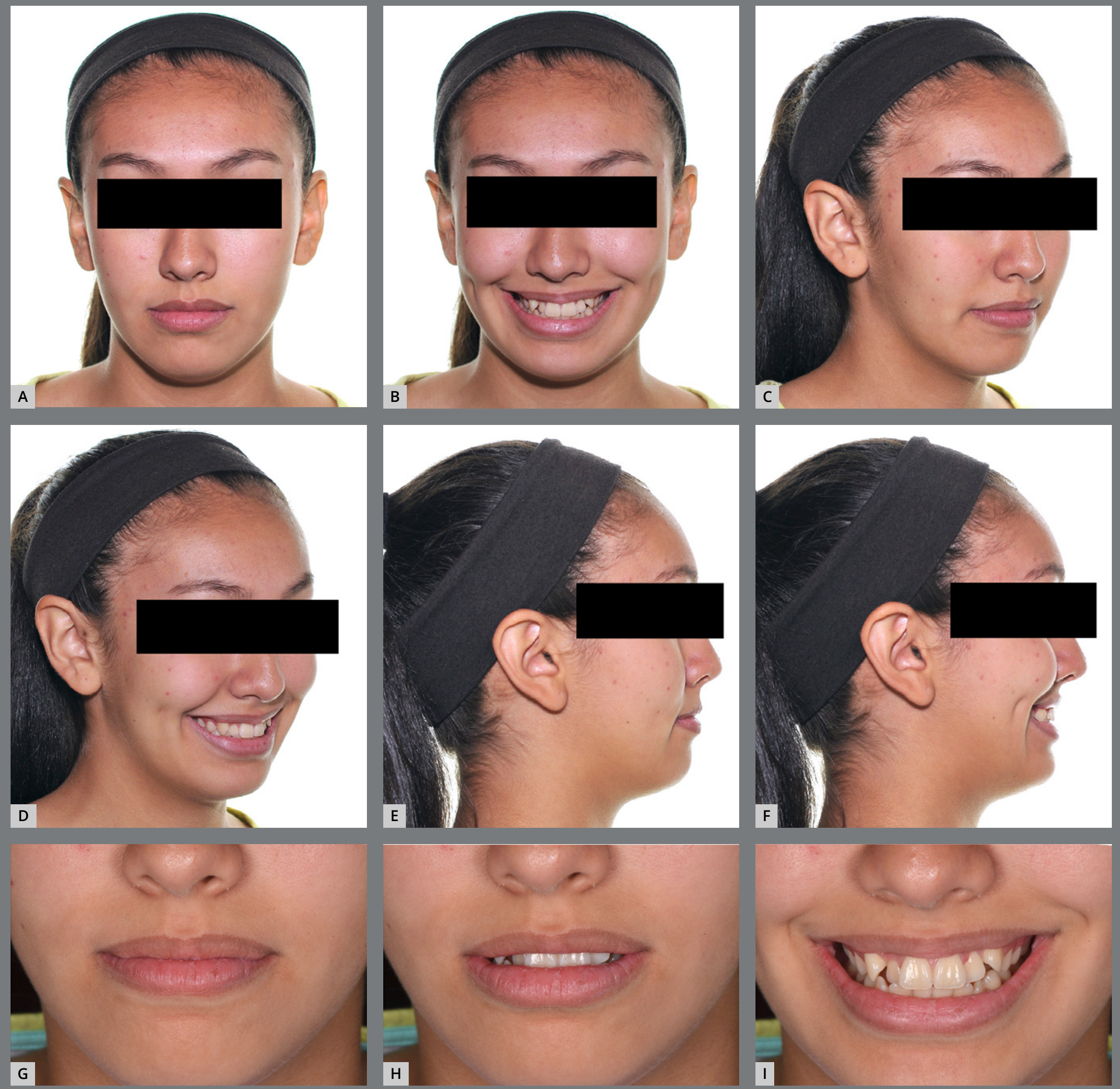

Figure 1: A-I) Pretreatment extraoral photographs. 
Matsumoto K, Tanna N - Maxillary protraction and vertical control utilizing skeletal anchorage for midfacial-maxillary deficiency
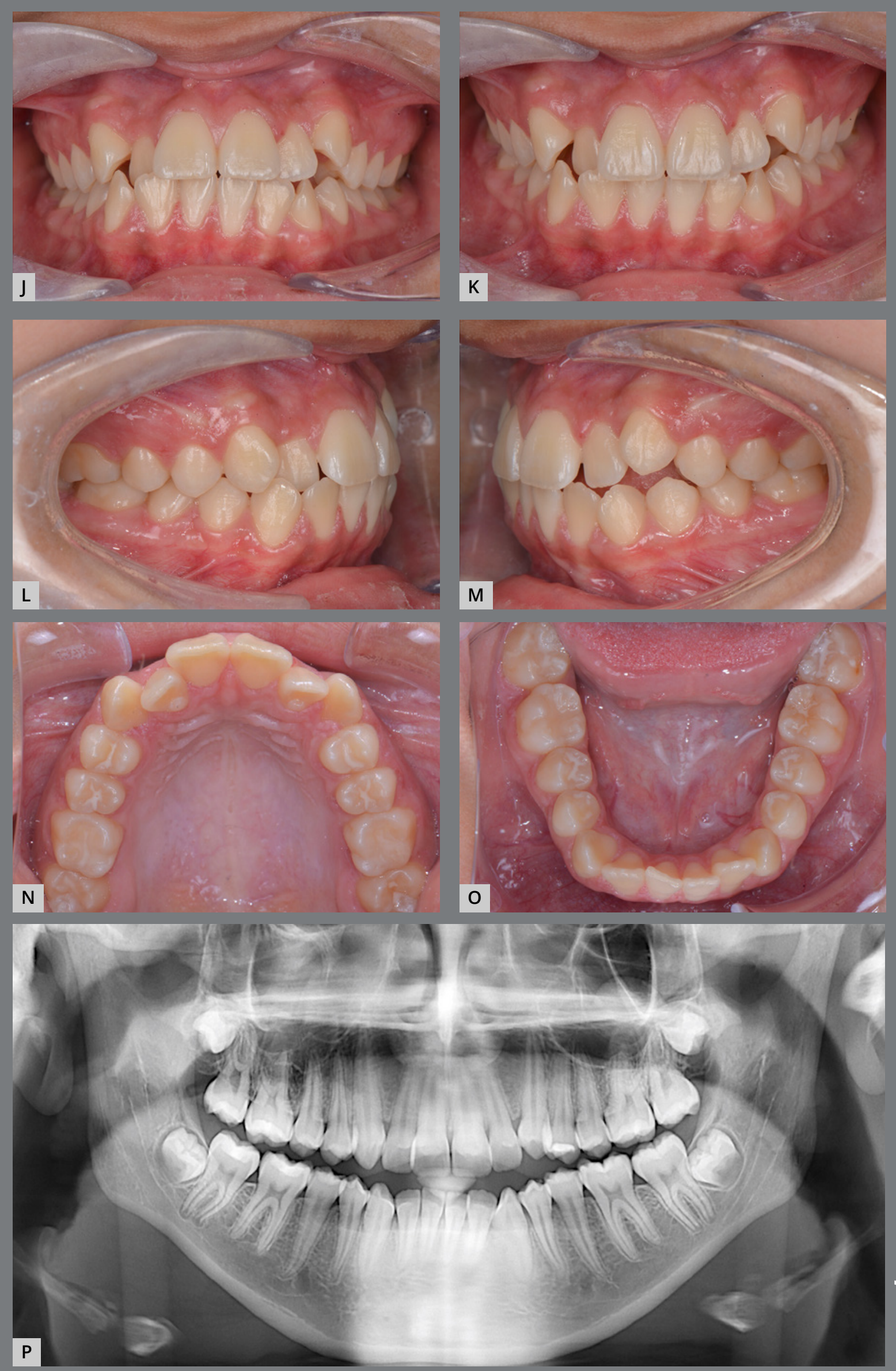

Figure 1 (continuation): J-0) Pretreatment intraoral photographs and P) panoramic radiograph. 
The pretreatment lateral cephalometric radiograph and tracing (Figs 1Q, 1R) and analysis (Table 1) demonstrated a Class III skeletal pattern $\left(\mathrm{ANB}=0.5^{\circ}\right.$, Wits appraisal $=-5.2 \mathrm{~mm}$ ), with a retrognathic maxilla $\left(\mathrm{SNA}=74.2^{\circ}\right)$ and mandible $\left(\mathrm{SNB}=73.7^{\circ}\right)$. The SN.MP angle of $42.4^{\circ}$ and the FMA of $33.6^{\circ}$ reflected a high mandibular plane angle and open bite pattern. The maxillary incisors were proclined $\left(\mathrm{U} 1 . \mathrm{SN}=107.2^{\circ}\right)$. The mandibular incisors were proclined $\left(\mathrm{IMPA}=97.5^{\circ}\right)$ and procumbent $(\mathrm{L} 1 . \mathrm{NB}=7.6 \mathrm{~mm})$.

The growth potential was evaluated, and cervical vertebrae maturation stage ${ }^{8}$ demonstrated CS4, which indicated that her peak mandibular growth occurred within 1-2 years before this stage. Radiographic evaluation of skeletal maturation with the hand-wrist film ${ }^{9}$ showed the ulna and the radial epiphyses were fused (skeletal maturation indicator = SMI 11), and her skeletal age was 16 years old (Fig 1S).
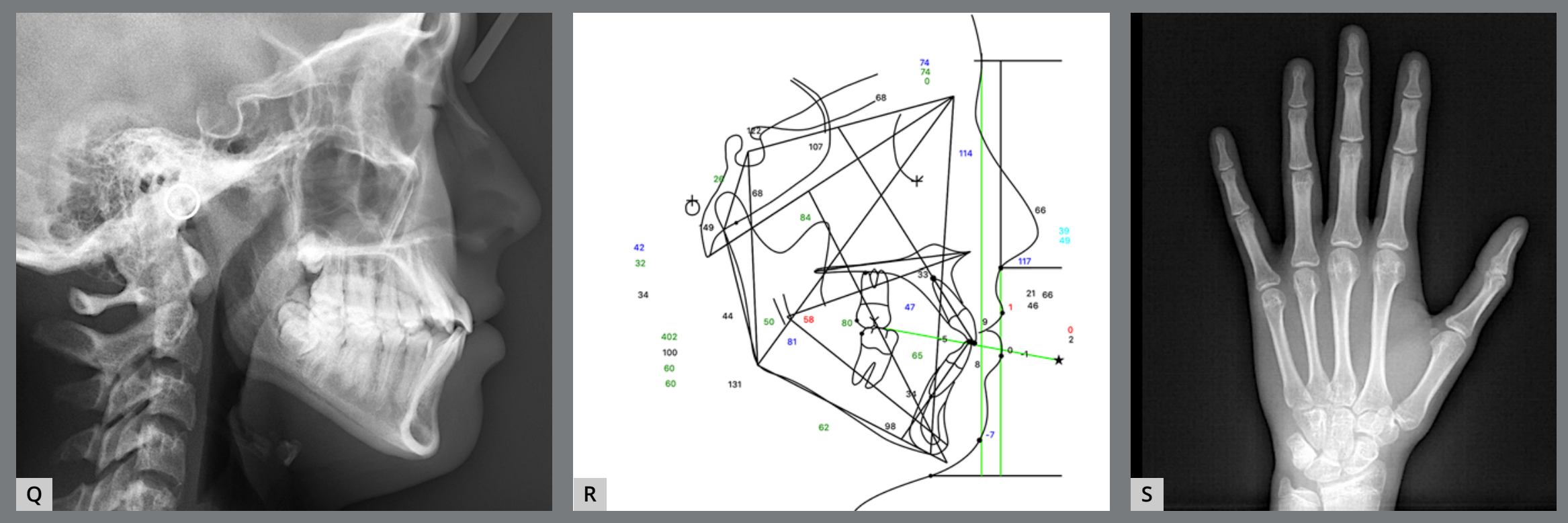

Figure 1 (continuation): Pretreatment lateral cephalometric radiograph (Q), tracing (R), and hand-wrist radiograph (S). 
Table 1: Cephalometric measurements at the stages of treatment and retention.

\begin{tabular}{|c|c|c|c|c|c|c|c|c|}
\hline Measurement & Norm & $\begin{array}{c}\text { Pretreat- } \\
\text { ment } \\
\text { (Pre-tx) }\end{array}$ & $\begin{array}{c}\text { Post-RPE } \\
\text { with } \\
\text { facemask }\end{array}$ & $\begin{array}{l}\text { Post-treat- } \\
\text { ment } \\
\text { (Post-tx) }\end{array}$ & Retention & $\begin{array}{l}\text { Change } \\
\text { (Pre-tx } \\
\text { and } \\
\text { post-RPE) }\end{array}$ & $\begin{array}{l}\text { Change } \\
\text { (Pre-tx } \\
\text { and } \\
\text { post-tx) }\end{array}$ & $\begin{array}{l}\text { Change } \\
\text { (Post-tx } \\
\text { and } \\
\text { retention) }\end{array}$ \\
\hline \multicolumn{9}{|l|}{ Skeletal } \\
\hline SNA (degrees) & 81.6 & 74.2 & 75.8 & 75.9 & 75.6 & 1.6 & 1.7 & -0.3 \\
\hline SNB (degrees) & 78.6 & 73.7 & 72.4 & 72.9 & 72.3 & -1.3 & -0.8 & -0.6 \\
\hline ANB (degrees) & 2.9 & 0.5 & 3.4 & 3.2 & 3.2 & 2.9 & 2.5 & 0.2 \\
\hline Wits (mm) & 1.1 & -5.2 & 0.8 & -1.5 & -1.5 & 6.0 & 3.5 & 0.2 \\
\hline SN.GoGn (degrees) & 31.8 & 42.4 & 44.2 & 45.4 & 45.4 & 1.8 & 0.2 & 2.8 \\
\hline FMA (degrees) & 20.6 & 32.2 & 33.4 & 34.3 & 34.3 & 1.2 & .03 & 1.8 \\
\hline \multicolumn{9}{|l|}{ Dental } \\
\hline U1.SN (degrees) & 104.0 & 107.2 & 104.8 & 101.2 & 101.2 & -2.4 & -4.4 & -1.6 \\
\hline U1.NA (degrees) & 22.7 & 33.0 & 29.0 & 25.6 & 25.6 & -4.0 & -6.9 & -0.5 \\
\hline U1-NA (mm) & 4.3 & 8.5 & 6.7 & 6.0 & 6.0 & -1.8 & -0.9 & -1.6 \\
\hline L1.NB (degrees) & 29.1 & 33.6 & 29.1 & 32.6 & 32.6 & -4.5 & -4.1 & 3.1 \\
\hline L1-NB (mm) & 6.6 & 7.6 & 6.9 & 8.3 & 8.3 & -0.7 & 1.4 & -0.7 \\
\hline IMPA (degrees) & 98.0 & 97.5 & 92.6 & 94.9 & 94.9 & -4.9 & -3.5 & 0.9 \\
\hline \multicolumn{9}{|l|}{ Soft tissue } \\
\hline $\begin{array}{l}\text { Nasolabial angle } \\
\text { (degrees) }\end{array}$ & 105.0 & 117.2 & 113.5 & 105.6 & 111.5 & -3.7 & -11.6 & 5.9 \\
\hline $\begin{array}{l}\text { L lip to E-plane } \\
(\mathrm{mm})\end{array}$ & 0.0 & -0.7 & -0.5 & 2.7 & 1.3 & 0.2 & 3.4 & -1.4 \\
\hline
\end{tabular}

The etiology of her malocclusion may have been a combination of genetic and developmental factors. She had a skeletal Class III with bilateral Angle Class I molar relationships. Hence, the possible explanation would be early loss of maxillary deciduous dentition. 


\section{TREATMENT OBJECTIVES}

The treatment objectives were: (1) to increase facial convexity, with maxillary protraction; (2) to minimize the increase of the mandibular plane angle, with vertical control; (3) to increase incisor display; (4) to maintain broad arch form, to create a more balanced esthetic face; (5) to distalize maxillary molars; and (6) to maintain mandibular molars, to achieve Class I molar relationship.

\section{TREATMENT ALTERNATIVES}

Three treatment options were considered.

1. Extraction of four first premolars, to align the maxillary lateral incisors, retract mandibular incisors, and close the remaining spaces reciprocally, to achieve anterior coupling and a Class I canine relationship. This treatment would provide the solution of the arch-length deficiency and possibly a stable tooth alignment. However, this option would not improve the retrusive maxillary complex, and could even worsen the profile.

2. Extensive interproximal reduction (IPR) on maxillary and mandibular anterior teeth, to relieve crowding. The disadvantage of this option would be proclination of both maxillary and mandibular incisors, and maintenance of the retrusive maxilla. Hence, the facial and smile esthetics would not be optimized. 
3. Maxillary expansion with a TAD-supported Haas rapid palatal expander (TAD-Haas RPE) and protraction with a facemask. Distalization of maxillary posterior teeth with the TADs would also provide predictable vertical control. Since she was at post-pubertal growth spurt, being a skeletally mature patient, conventional RPE and/or facemask treatment would provide more dental and less skeletal correction. The orthopedic effects of TAD-Haas RPE and facemask treatment would allow the maxilla to come forward and downward, while minimizing negative dental compensation. This treatment option would enhance both the profile and smile esthetics, by increasing incisal display. However, the patient's compliance would be the key for this treatment option.

The patient and her parents rejected the options of extraction and extensive IPR. The third option, TAD-Haas RPE with a facemask, was accepted because of the optimal facial and smile esthetics without tooth extraction.

\section{TREATMENT PROGRESS}

A TAD-Haas RPE, consisting of acrylic palatal coverage and bands attached to the maxillary first molars, was applied in order to minimize the buccal tipping of the alveolar bone and the molar axes (Figs 2A-D). Additionally, facemask hooks were soldered to the bands. The expander was activated by turning the jackscrew once a day for 32 days, and the facemask 
initiated simultaneously. Elastics were connected to the outer bow of the facemask in a $30^{\circ}$ downward and forward direction, delivering $500 \mathrm{~g}$ of force per side for 13 to 14 hours per day, for 6 months (Figs 2E-H). The expansion resulted in $8 \mathrm{~mm}$ at the jackscrew. After the expansion was completed, the
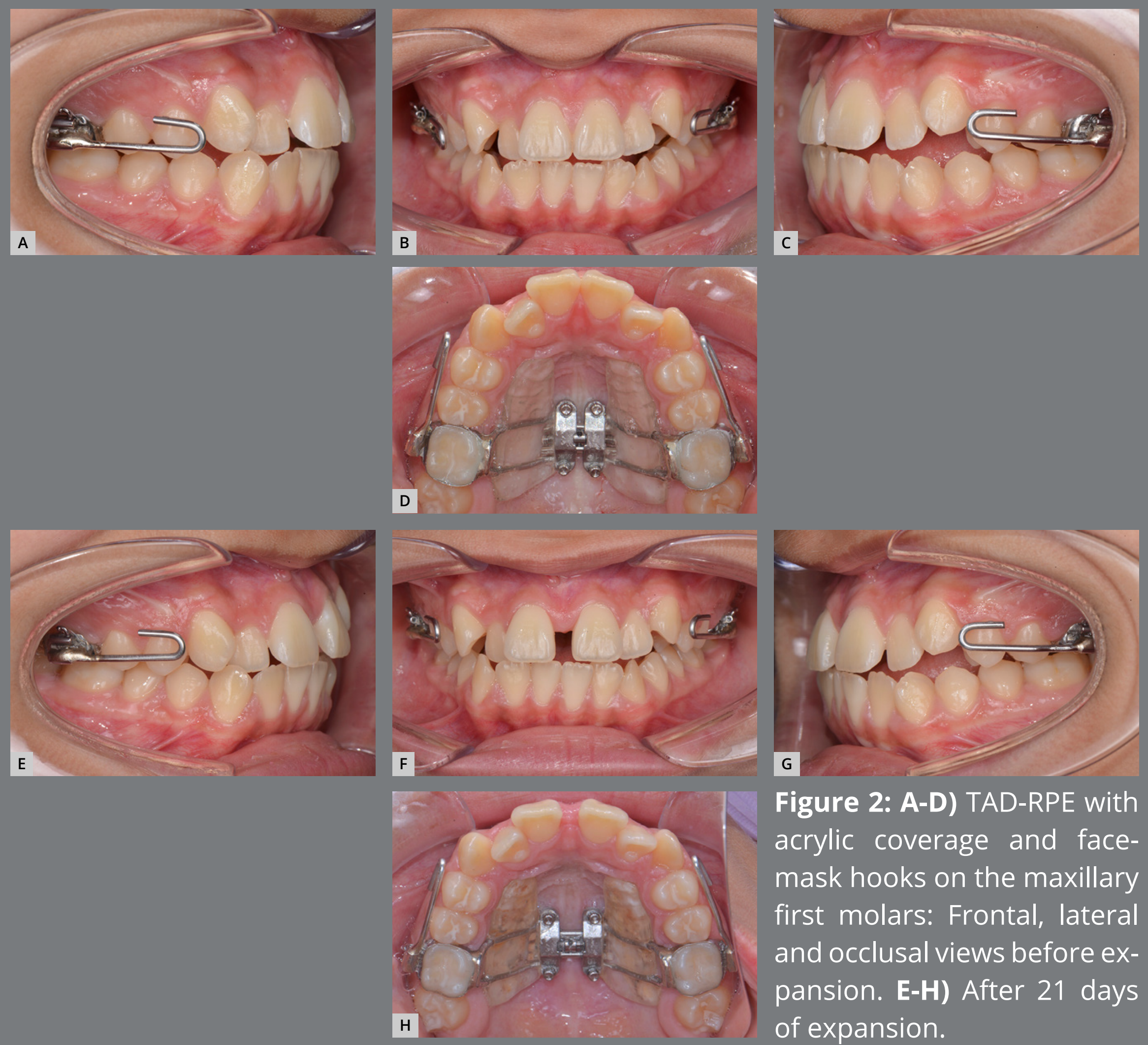

Figure 2: A-D) TAD-RPE with acrylic coverage and facemask hooks on the maxillary first molars: Frontal, lateral and occlusal views before expansion. E-H) After 21 days of expansion. 
mandibular arch was bonded with self-ligating brackets (0.022in preadjusted appliances, Roth prescription) (Figs 3A-F). A lateral cephalometric radiograph was taken after TAD-Haas RPE and facemask treatment (Fig 3G). Cephalometric tracing of post-TAD-Haas RPE and facemask treatment (Fig 3H) showed the maxilla protracted forward and downward, and there was clockwise rotation of the mandible. Both maxillary and mandibular incisors retroclined, and there was minimum movement of both maxillary and mandibular molars. Leveling and alignment was started with 0.014-in Nitinol, and progressed to $0.019 \times 0.025$-in stainless steel archwires. After completion of the facemask treatment, only molar bands of the TAD-Haas RPE were removed and converted to molar brackets, but the RPE was maintained, the maxillary arch was bonded, and the leveling and alignment phase was initiated. Palatal attachments on maxillary first premolars and first molars were connected with the TADs, to increase anchorage and control the vertical dimension (Figs 4A-F). The maxillary distalization for Class II correction was initiated bilaterally, with open coils between second premolar and first molar. Then, sequential distalization was accomplished (Figs 4G-L). Once anterior teeth were coupled, the TAD-Haas RPE was removed. Finishing and detailing was completed. The patient was debonded and retained with a maxillary Hawley wraparound and fixed mandibular canine to canine retainer. Treatment was completed in 26 months. 
Matsumoto K, Tanna N - Maxillary protraction and vertical control utilizing skeletal anchorage for midfacial-maxillary deficiency
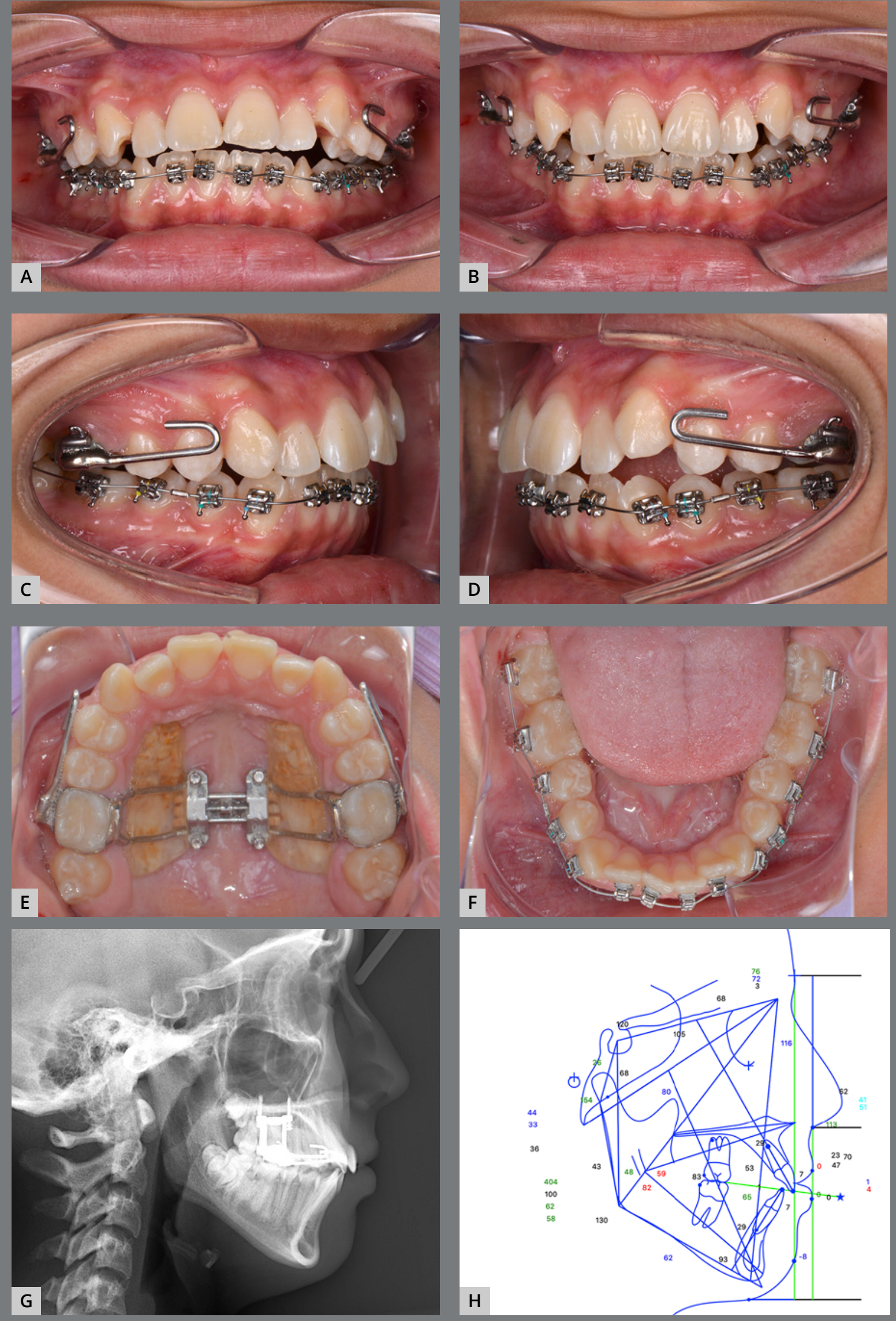

Figure 3: Intraoral photographs (A-F), lateral cephalometric radiograph (G), and tracing $\mathbf{( H )}$ at completion of TAD-Haas RPE and facemask treatment. 

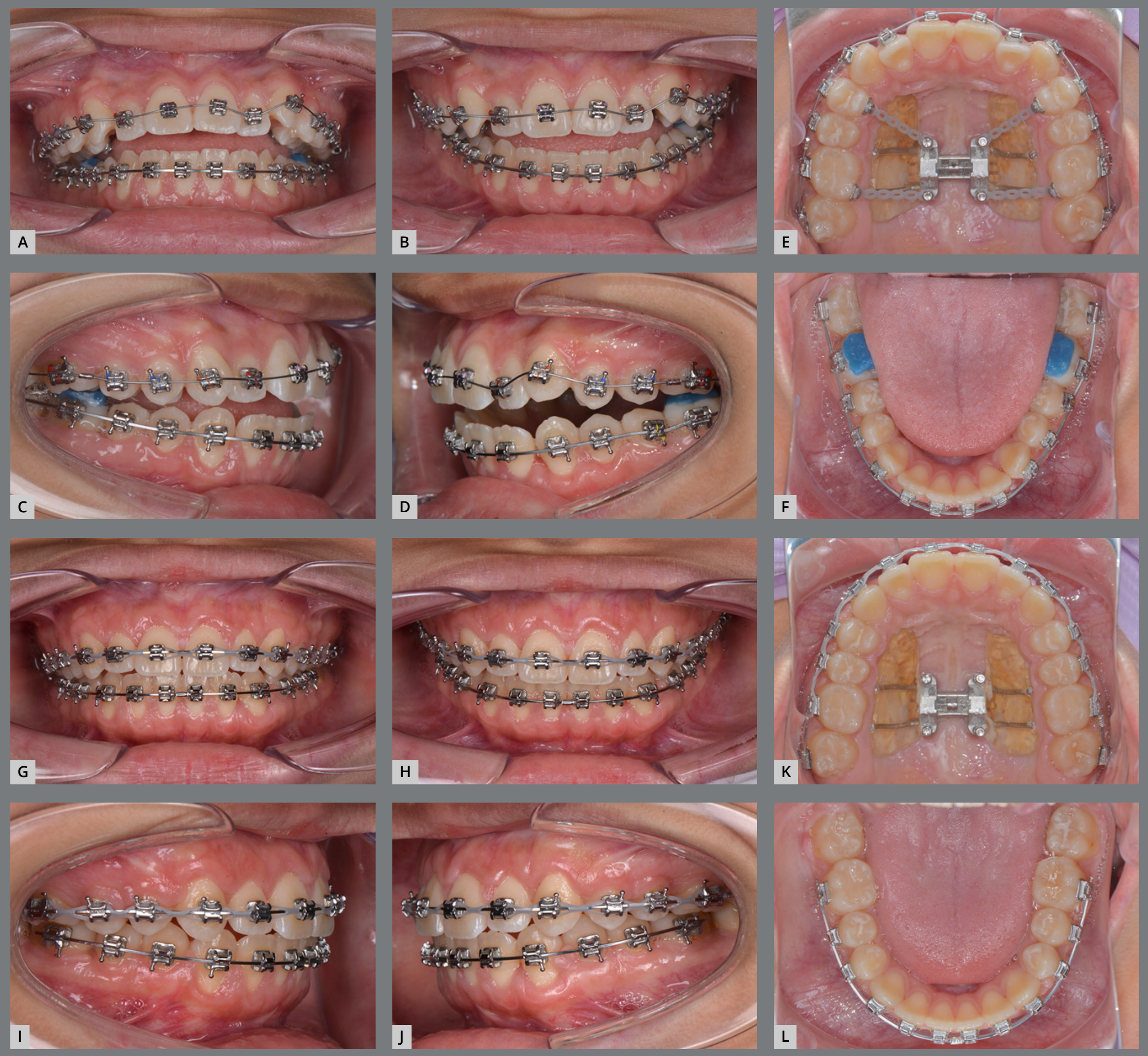

Figure 4: A-F) Molar bands were removed and mandibular leveling and alignment was completed. G-L) Completion of maxillary molar distalization. 


\section{TREATMENT RESULTS}

The facial profile was enhanced, with maxillary lip support and nasolabial angle reduction, utilizing maxillary protraction (Figs 5A-I). Flattened cheeks became more prominent. The smile esthetics was enhanced, with optimal anterior tooth display, adequate gingival display, and consonant smile arc. Ideal anterior coupling, midline correction, and Class I canine and molar relationships were achieved (Figs 5J-O). The post-treatment panoramic radiograph showed excellent root parallelism and minimum root resorption (Fig 5P). The post-treatment lateral cephalometric radiograph, tracing and the superimpositions exhibited maxillary downward and forward movement (Figs 5Q-R, Figs 6A-C). The changes in SNA $\left(+2.1^{\circ}\right)$, ANB $\left(+2.3^{\circ}\right)$, and Wits appraisal (+3.0 mm) demonstrated an improvement of the skeletal Class III. The maxillary incisors were retroclined, retracted, and extruded. Mandibular incisors were retroclined and extruded. Maxillary first molars were slightly distalized, and there was no vertical change. 

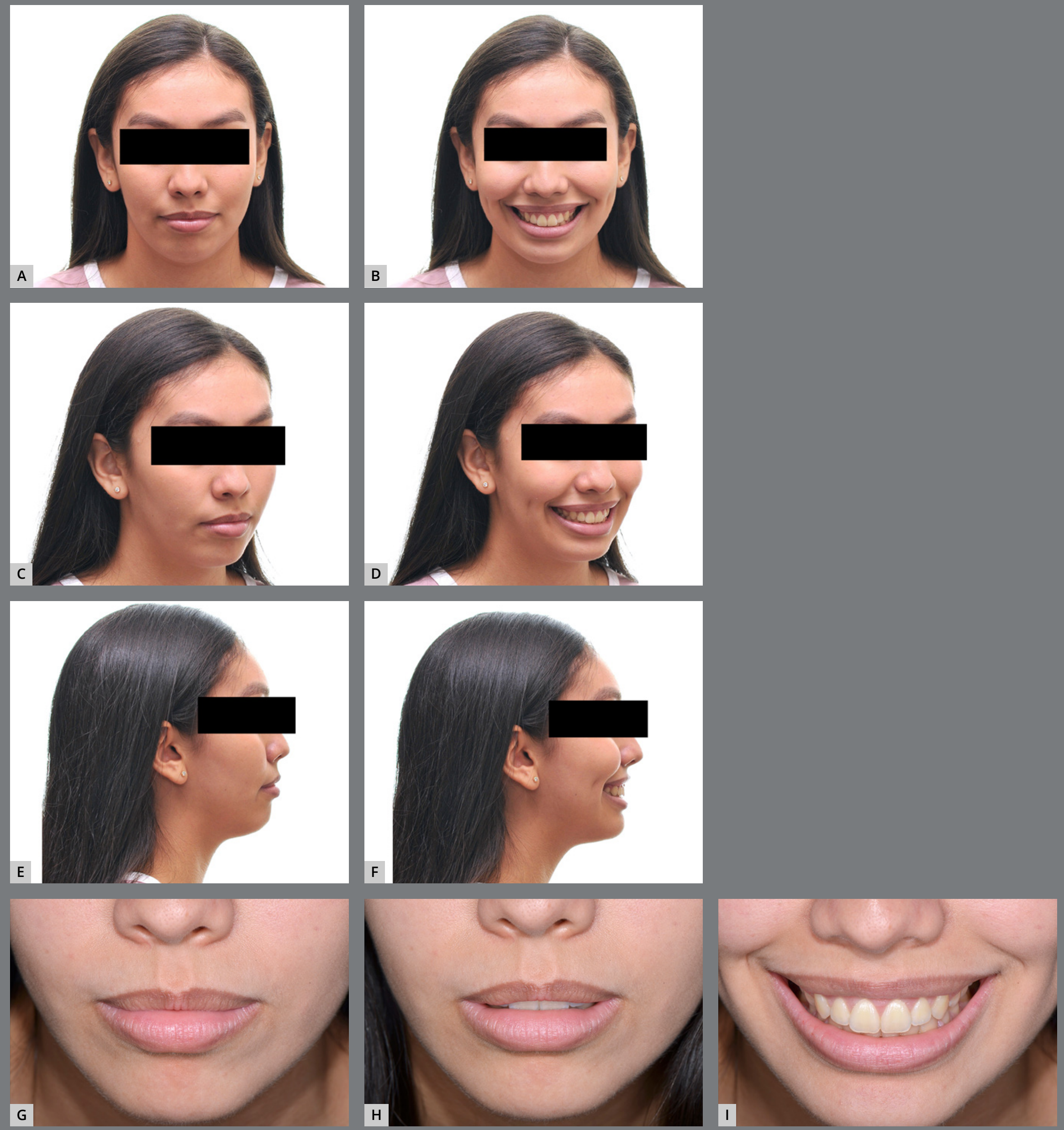

Figure 5: A-I) Post-treatment extraoral photographs. 
Matsumoto K, Tanna N - Maxillary protraction and vertical control utilizing skeletal anchorage for midfacial-maxillary deficiency
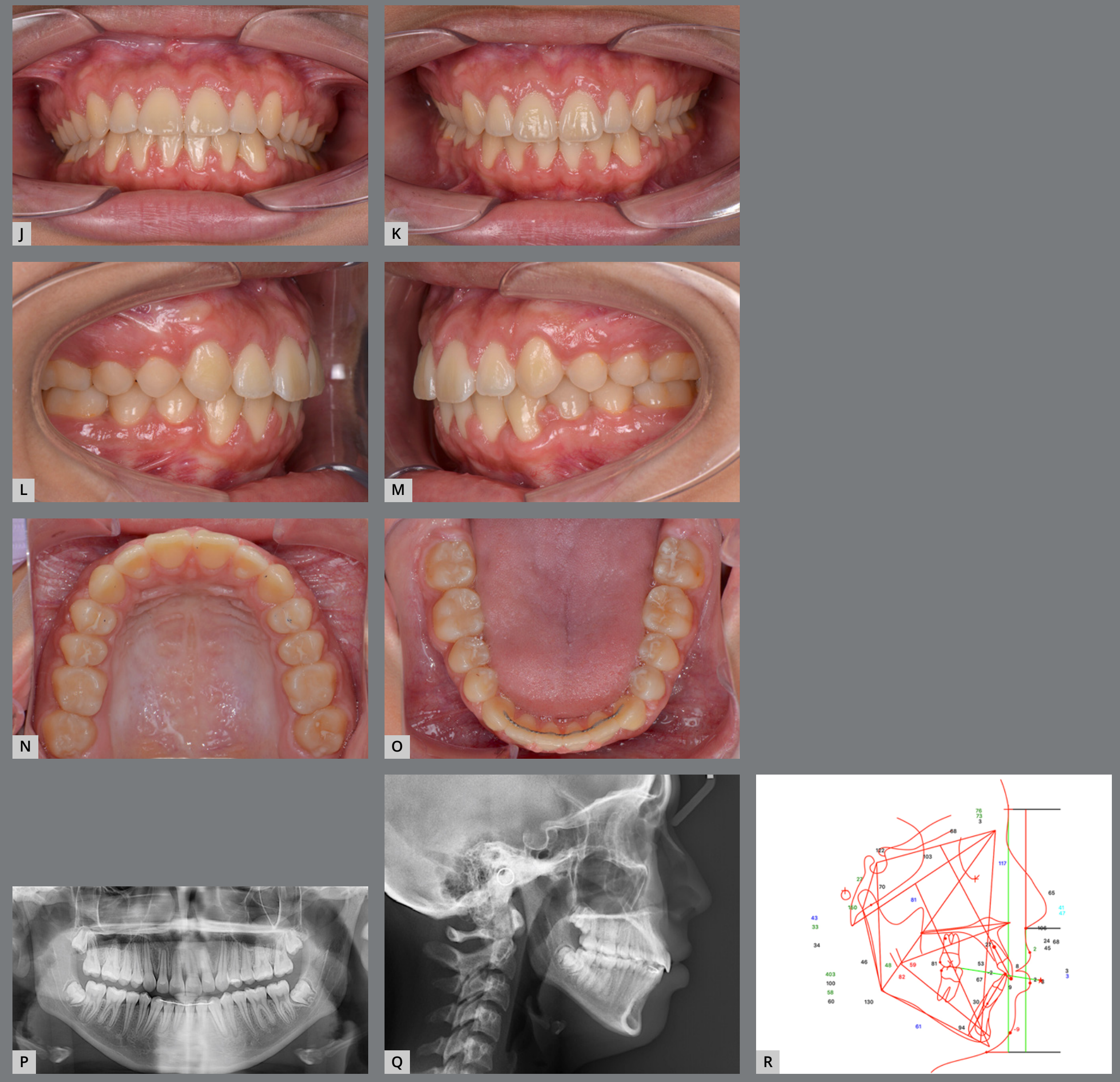

Figure 5 (continuation): Post-treatment intraoral photographs (J-O), panoramic radiograph (P), cephalometric radiograph $(\mathbf{Q})$, and tracing $(\mathbf{R})$. 
Matsumoto $\mathrm{K}$, Tanna N - Maxillary protraction and vertical control utilizing skeletal anchorage for midfacial-maxillary deficiency
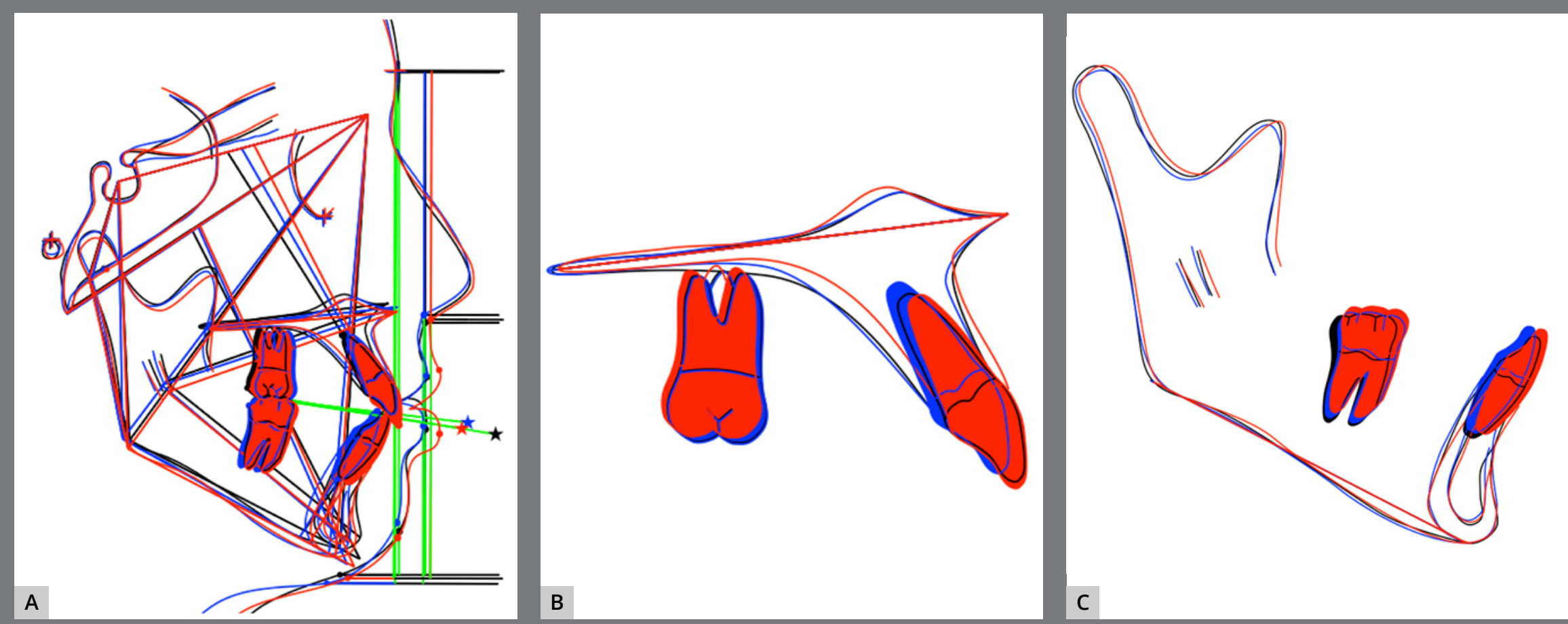

Figure 6: Pretreatment (black), post-TAD-Haas RPE and facemask treatment (blue) and post-treatment (red) cephalometric tracings superimpositions: A) superimposed on the sella-nasion plane at sella; B) superimposed on the palatal plane at ANS; C) superimposed on the mandibular plane at menton.

Mandibularfirst molarswere extruded. Adequate vertical control prevented a change in the mandibular plane angle even though facemask treatment can increase the vertical dimension (Table 1). Cone Beam Computed Tomography (CBCT) images at post-expansion confirmed a 5.7-mm skeletal expansion at the level of the first molars, which was maintained after the orthodontic treatment (Figs 7A-C, Table 2). 
Matsumoto K, Tanna N - Maxillary protraction and vertical control utilizing skeletal anchorage for midfacial-maxillary deficiency
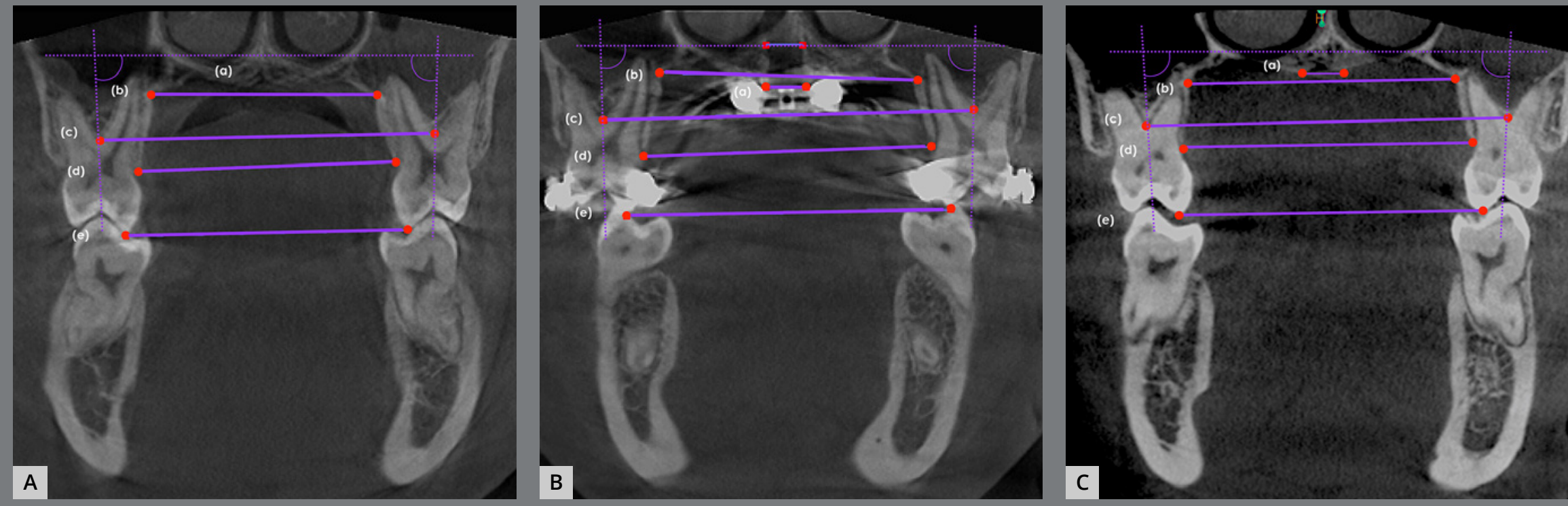

Figure 7: Measurements at pretreatment (A), post-expansion (B), and post-treatment (C). $a=$ suture $(\mathrm{mm}), b=\mathrm{U} 6$ basal bones $(\mathrm{mm}), \mathrm{c}=\mathrm{U} 6$ furcations $(\mathrm{mm}), \mathrm{d}=\mathrm{U} 6 \mathrm{CEJs}(\mathrm{mm})$, and e= U6 palatal cusps $(\mathrm{mm})$

Table 2: Measurements in the transverse dimension at pretreatment, post-expansion and post-treatment.

\begin{tabular}{|c|c|c|c|c|c|c|c|}
\hline \multirow{2}{*}{$\begin{array}{c}\text { Jackscrew } \\
\text { 8mm expansion }\end{array}$} & \multirow{2}{*}{$\begin{array}{l}\text { Pretreat- } \\
\text { ment } \\
\text { (A) }\end{array}$} & \multirow{2}{*}{$\begin{array}{l}\text { Post-expan- } \\
\text { sion } \\
\text { (B) }\end{array}$} & \multirow{2}{*}{$\begin{array}{l}\text { Post-treat- } \\
\text { ment } \\
\text { (C) }\end{array}$} & \multicolumn{3}{|c|}{ Differences } & \multirow{2}{*}{$\begin{array}{l}\begin{array}{c}\text { Percentage } \\
\text { of jackscrew }\end{array} \\
\text { B-A }\end{array}$} \\
\hline & & & & B-A & C-B & C-A & \\
\hline Suture (mm) & 0.00 & 5.68 & 5.66 & 5.68 & -0.02 & 5.66 & $71.0 \%$ \\
\hline U6 basal bones (mm) & 31.59 & 36.64 & 36.56 & 5.05 & -0.08 & 4.97 & $63.1 \%$ \\
\hline U6 furcations (mm) & 46.69 & 52.43 & 49.79 & 5.74 & -2.64 & 3.10 & $71.8 \%$ \\
\hline U6 CEJs (mm) & 35.89 & 40.82 & 40.08 & 4.93 & -0.74 & 4.19 & $61.6 \%$ \\
\hline U6 palatal cusps (mm) & 39.25 & 46.00 & 41.77 & 6.75 & -4.23 & 2.52 & $84.4 \%$ \\
\hline UR6 inclination (degrees) & 87.0 & 89.0 & 87.0 & 2.0 & -2.0 & 0.0 & - \\
\hline UL6 inclination (degrees) & 88.0 & 88.0 & 87.0 & 0.0 & -1.0 & -1.0 & - \\
\hline $\begin{array}{l}\text { UR alveolar bone } \\
\text { inclination (degrees) }\end{array}$ & 101.0 & 101.0 & 98.5 & 0.0 & -2.5 & -2.5 & - \\
\hline $\begin{array}{l}\text { UL alveolar bone } \\
\text { inclination (degrees) }\end{array}$ & 106.0 & 102.0 & 105.0 & -4.0 & 3.0 & -1.0 & - \\
\hline
\end{tabular}


At the 18-month retention visit, excellent stability of the treatment results was shown (Figs 8A-D). Patient's profile has been maintained and there was optimal lip projection. Angle Class I molar relationship, anterior overjet and overbite were maintained (Figs $8 \mathrm{E}-\mathrm{J}$ ). Figures $8 \mathrm{~K}$ and $8 \mathrm{~L}$ depict the profile changes through the treatment. The facial profile was improved, with maxillary lip support and improved nasolabial angle, and more prominent cheeks. The lateral cephalometric radiograph and tracing of post-treatment and 18-month retention (Figs $8 \mathrm{M}$ and $8 \mathrm{~N}$ ) showed the maxilla was stable, mandible presented backward rotation, and maxillary incisors were tipped back slightly. Mandibular dentition was retained. 

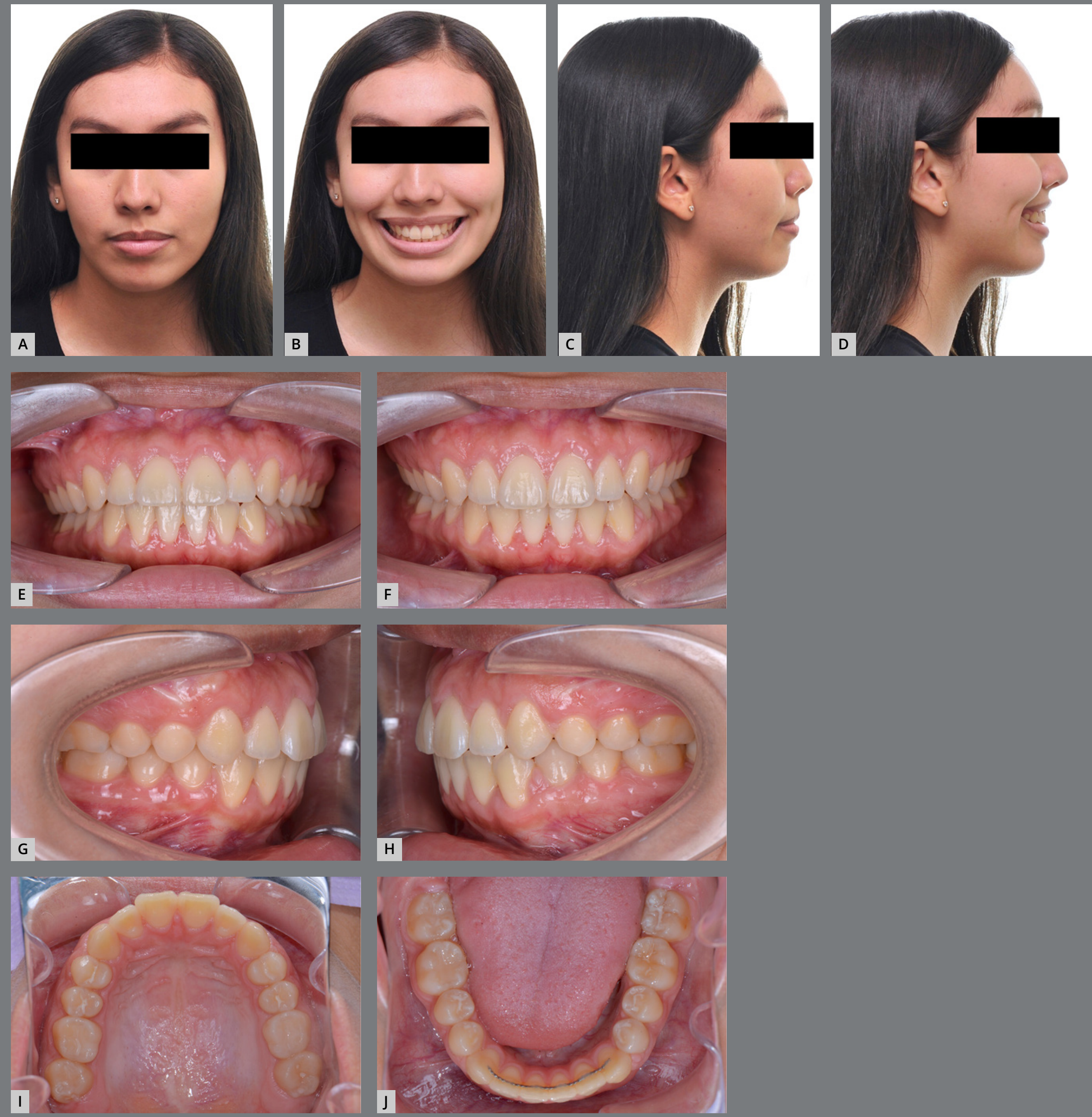

Figure 8: Extraoral (A-D) and intraoral photographs (E-J) at 18-month retention. 

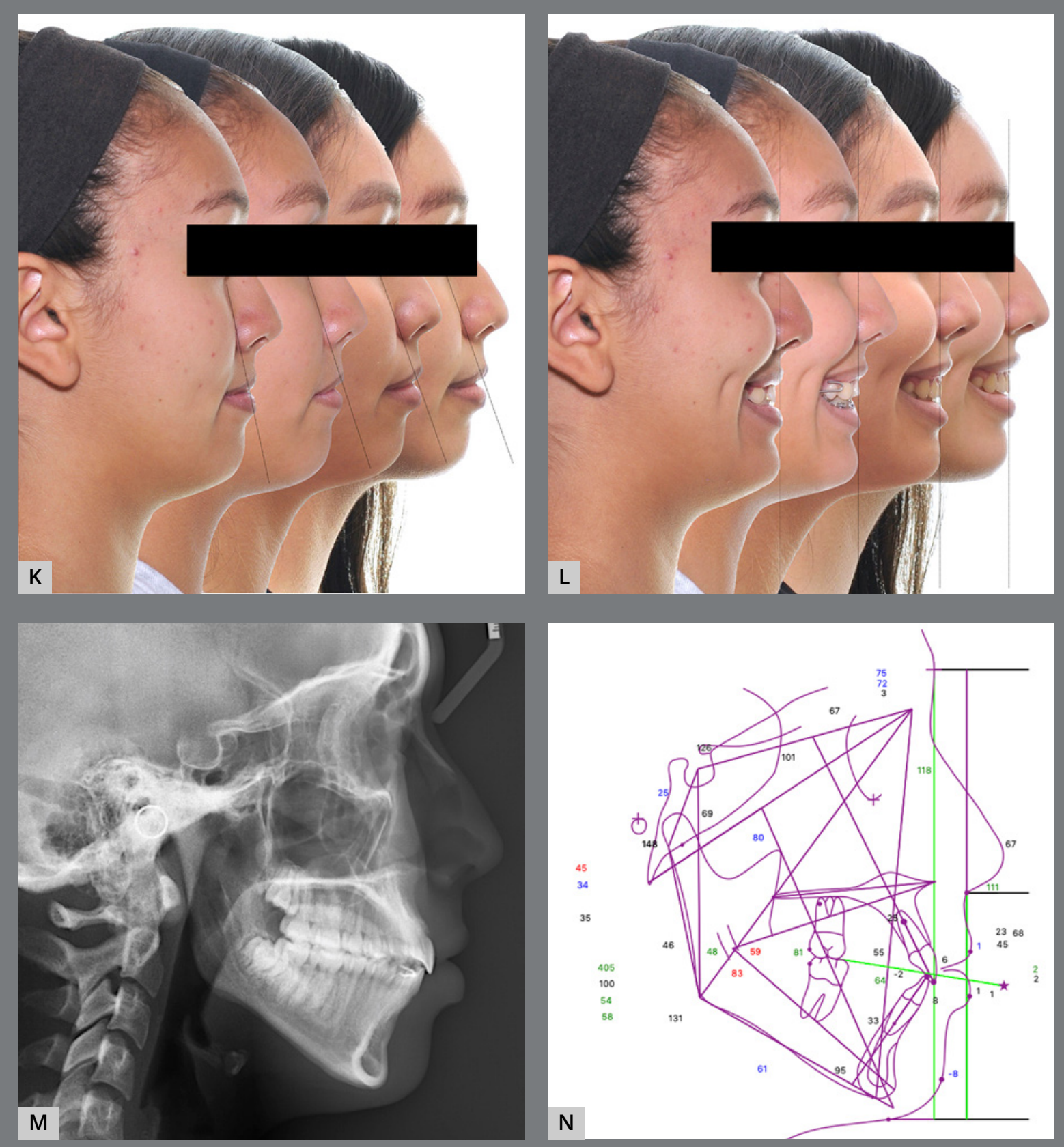

Figure $\mathbf{8}$ (continuation): K-L) Profile changes through the treatment. Cephalometric radiograph (M) and tracing (N) at 18-month retention.

\section{DISCUSSION}

Systematic reviews and meta-analyses have shown that the orthopedic effect produced by maxillary protraction allows the maxilla to move forward and downward. Additionally, there is mandibular downward and backward rotation, along with dental effects. ${ }^{2,10,11}$ The efficacy of facemask treatment 
for skeletal Class III patients has been discussed regarding the timing, treatment duration, impact of the combination with RPE, and usage of skeletal anchorage devices. Facemask treatment is effective when patients starting the treatment are younger or older children.6,12 However, after 10 years of age, decrease of the skeletal changes, increase of dental compensation, and longer treatment time were reported. ${ }^{1-5,11,12}$ Even though skeletal Class III correction might be achieved in all age groups (3-12 years old), treatment should be started as soon as the diagnosis is made, because younger patients showed greater and faster results in less time. ${ }^{12}$ In the present article, the patient was a 13-year-5-months-old female in post menarche, CS4 (CVS) and 16-year-old skeletal age, according to a hand-wrist film. Her growth spurt has passed, and she is skeletally mature. At this age, facemask treatment alone would not provide the skeletal improvements, but most likely would have dental effects.

CBCT images at post-expansion confirmed the skeletal expansion in the midpalatal suture at the level of the first molars was $5.7 \mathrm{~mm}$, which was $71 \%$ of the jackscrew expansion; the first molars tipped $2.0^{\circ}$ buccally, and alveolar bone inclination changed $4.0^{\circ}$ palatally (Figs 3A-F and Table 2). Garrett et al. ${ }^{13}$ reported $38 \%$ of skeletal expansion in the first molar region with the Hyrax RPE in patients (mean age $=13.8$ years). A mean of $52.82 \%(4.33 \mathrm{~mm})$ midpalatal suture opening at the first molars 
was obtained in children (mean age $=9.9$ years) who were treated with a bonded RPE. ${ }^{14}$ Lin et al. ${ }^{15}$ evaluated the immediate effects of RPE on the transverse skeletal and dentoalveolar changes with bone-borne expander (TAD-RPE) and tooth-borne expander (Hyrax expander) in late female adolescents. They reported the Hyrax group produced more buccal tooth tipping $\left(13.1^{\circ}\right.$ vs $\left.2.3^{\circ}\right)$, more buccal alveolar bone bending $\left(7.3^{\circ}\right.$ vs $\left.2.1^{\circ}\right)$, and less skeletal expansion (1.14 mm vs $1.99 \mathrm{~mm}$ ) at the maxillary-first-molar level. Additionally, they found that significant buccal dehiscence occurred in the Hyrax group.

In summary, bone- or tissue-borne expanders produced greater orthopedic effects and fewer dentoalveolar side effects, compared to the tooth-borne expanders. TAD-Haas RPE showed excellent results for maximizing the skeletal changes and minimizing the dentoalveolar compensations. As a long-term stability after expansion, RPE treatment did not influence the sagittal position of the apical jaw bases or the facial vertical dimension. ${ }^{16}$

RPE treatment alone has shown that there is downward and forward movement of the maxilla. ${ }^{17-19}$ The mean SNA, ANB, mandibular plane angle (MP.SN) increased by $0.35^{\circ}, 1.00^{\circ}$, $1.72^{\circ}$, respectively. ${ }^{19}$ As dental changes, average decreases of the U1.SN and IMPA were reported as $0.43^{\circ}$ and $0.59^{\circ}$, respectively. ${ }^{19}$ Therefore, RPE can be beneficial in skeletal Class III patients for promoting maxillary forward movement and incisal uprighting. 
Regarding the facemask in combination with RPE, some studies support that combination treatment is better than facemask alone, ${ }^{20-22}$ while others advocated that there were no significant differences between expansion and non-expansion groups with facemask therapy under the age of 10 years. ${ }^{23-25}$ In a systematic review, ${ }^{2}$ the treatment duration was much longer in the non-expansion group. More skeletal effect and less dental change were produced with the RPE, whereas more dental change was produced with the non-expansion appliance. Additionally, Kim et al. ${ }^{2}$ speculated that the more skeletal effects and less dental changes might be expected if the RPE with a palatal acrylic was utilized to enhance the anchorage. Hence, in the preset case, it was decided to combine a palatal acrylic support to the RPE.

Currently, facemask with TAD-RPE, ${ }^{26-29}$ or direct bone-anchored maxillary protraction devices (BAMP) ${ }^{22}$ are available. Utilizing skeletal anchorage devices effectively allows for maxillary protraction, reduces dental compensation, and maximizes skeletal changes. Treatment of 16 growing Class III patients (mean age $9.5 \pm 1.3$ years) utilizing a hybrid Hyraxfacemask combination was evaluated and there was a significant improvement: $\mathrm{SNA}=+2.0^{\circ} ; \mathrm{SNB}=-1.2^{\circ} ; \mathrm{ANB}=+3.2^{\circ}$; Wits appraisal $=+4.1 \mathrm{~mm}$, with minimum change in vertical skeletal relationships and maxillary incisor inclination. ${ }^{26}$ 
Ngan et al. ${ }^{29}$ reported that patients (mean age 9.8 years) who were treated with the tooth-borne protraction had changes of SNA $=+0.69^{\circ}, \mathrm{SNB}=-1.73^{\circ}, \mathrm{ANB}=+2.42^{\circ}$, Wits $=+2.52 \mathrm{~mm}$, U1-SN $=+2.19^{\circ}$, and IMPA $=-4.99^{\circ}$, while the bone-borne protraction group (mean age 9.6 years) had changes of $\mathrm{SNA}=+1.59^{\circ}, \quad \mathrm{SNB}=-0.80^{\circ}, \quad \mathrm{ANB}=+2.40^{\circ}$, Wits $=+2.58 \mathrm{~mm}$, U1-SN $=-2.03^{\circ}$, and IMPA $=-1.67^{\circ}$. Therefore, the tooth-borne group had more maxillary incisor proclination, due to mesialization of posterior teeth with dental compensation, while the bone-borne group had less downward movement of the A-point, less mandibular plane opening, and more maxillary incisor eruption. Regarding the locations of TADs placement, anterior palate provides more bone thickness. The midpalatal area within $1 \mathrm{~mm}$ of the midsagittal suture had the thickest bone available in the whole palate, and the thickness of bone tended to decrease laterally and posteriorly. ${ }^{30}$ Maximum effective bone heights were detected within a T-shaped area at the midpoint of first premolars and at contact point first-second premolars. ${ }^{31}$ However, both researches mentioned that high interindividual variation was found and should be carefully considered by the clinician. Although successful results with BAMP in the late mixed or permanent dentition age of 10-14 years were reported, ${ }^{32}$ this option is less frequently used, due to the requirement of the surgeries for placement and removal of the miniplates. 
Considering all factors in this case report, TAD-Haas RPE with facemask treatment was utilized in order to maximize the skeletal changes, minimize the dental effects, and shorten the treatment duration. As the results of 5.7- $\mathrm{mm}$ maxillary skeletal expansion and protraction for six months, the changes of SNA, SNB, ANB, Wits, SN.GoGn, U1.SN, and IMPA were $+1.6^{\circ}$, $-1.3^{\circ},+2.9^{\circ},+6.0 \mathrm{~mm},+1.8^{\circ},-2.4^{\circ},+1.6^{\circ}$, and $-4.9^{\circ}$, respectively. The results for this post-growth-spurt patient were compatible or even preferable to a previous study ${ }^{29}$ in which 10-yearold children were treated with TAD-RPE and facemask.

Once the maxillary expansion and overcorrection of the maxillary protraction to an end-to-end Class II molar relationship was completed, the TADs for the RPE were utilized for controlling the vertical dimension and bilateral maxillary molar distalization (Figs 4A-L). During the phase II treatment, the TADs were connected with the attachments on the maxillary first premolars and molars, for controlling the posterior vertical dimension and increasing the anchorage against the molar distalization. According to a recent systematic review regarding the effects of TAD-supported maxillary molar distalization in Class II malocclusions, ${ }^{33}$ the mean molar distalization values varied from $1.8 \mathrm{~mm}$ to $6.4 \mathrm{~mm}$. In the present patient, $2-\mathrm{mm}$ distalization was accomplished with simple modification of the TAD-Haas RPE (Fig 6B). 
After 18-month retention, photographs and cephalometric tracing (Figs 8A-D, 8N and Table 1) showed a stable result of the maxillary protraction, mesialized maxillary molars, and uprighted maxillary incisors.

\section{CONCLUSION}

With skeletal anchorage and facemask treatment, orthodontists have the ability of expanding and protracting the maxilla without tipping maxillary molars buccally and without the risk of unfavorable periodontal consequences. A TAD-Haas RPE allowed to distalize molars and control the vertical dimension, while minimizing undesired consequences. 
AUTHORS' CONTRIBUTIONS

Kensuke Matsumoto (KM)

Nipul Tanna (NT)
Conception or design of the study:

KM, NT.

Data acquisition, analysis or

interpretation:

KM, NT.

Writing the article:

KM, NT.

Critical revision of the article:

KM, NT.

Final approval of the article:

KM, NT.

Overall responsibility:

KM, NT.

Patients displayed in this article previously approved the use of their facial and intraoral photographs.

The authors report no commercial, proprietary or financial interest in the products or companies described in this article. 


\section{REFERENCES}

1. Baccetti T, Tollaro I. A retrospective comparison of functional appliance treatment of Class III malocclusions in the deciduous and mixed dentitions. Eur J Orthod. 1998 Jun;20(3):309-17.

2. Kim JH, Viana MA, Graber TM, Omerza FF, BeGole EA. The effectiveness of protraction face mask therapy: a meta-analysis. Am J Orthod Dentofacial Orthop. 1999 Jun;115(6):675-85.

3. Merwin D, Ngan P, Hagg U, Yiu C, Wei SH. Timing for effective application of anteriorly directed orthopedic force to the maxilla. Am J Orthod Dentofacial Orthop. 1997 Sep;112(3):292-9.

4. Sung SJ, Baik HS. Assessment of skeletal and dental changes by maxillary protraction. Am J Orthod Dentofacial Orthop. 1998 Nov;114(5):492-502.

5. Baik HS. Clinical results of the maxillary protraction in Korean children. Am J Orthod Dentofacial Orthop. 1995 Dec;108(6):583-92.

6. Kapust AJ, Sinclair PM, Turley PK. Cephalometric effects of face mask/expansion therapy in Class III children: a comparison of three age groups. Am J Orthod Dentofacial Orthop. 1998 Feb;113(2):204-12.

7. Suda N, Ishii-Suzuki M, Hirose K, Hiyama S, Suzuki S, Kuroda T. Effective treatment plan for maxillary protraction: is the bone age useful to determine the treatment plan? Am J Orthod Dentofacial Orthop. 2000 Jul;118(1):55-62. 
8. Baccetti T, Franchi L, McNamara JA Jr. The cervical vertebral maturation (CVM) method for the assessment of optimal treatment timing in dentofacial orthopedics. Semin Orthod. 2005;11:119-29.

9. Fishman LS. Radiographic evaluation of skeletal maturation. A clinically oriented method based on hand-wrist films. Angle Orthod. 1982 Apr;52(2):88-112.

10. Cordasco G, Matarese G, Rustico L, Fastuca S, Caprioglio A, Lindauer $S$ J, et al. Efficacy of orthopedic treatment with protraction facemask on skeletal Class III malocclusion: a systematic review and metaanalysis. Orthod Craniofac Res. 2014 Aug;17(3):133-43.

11. Woon SC, Thiruvenkatachari B. Early orthodontic treatment for Class III malocclusion: A systematic review and meta-analysis. Am J Orthod Dentofacial Orthop. 2017 Jan;151(1):28-52.

12. Saadia M, Torres E. Sagittal changes after maxillary protraction with expansion in class III patients in the primary, mixed, and late mixed dentitions: a longitudinal retrospective study. Am J Orthod Dentofacial Orthop. 2000 Jun;117(6):669-80.

13. Garrett BJ, Caruso JM, Rungcharassaeng K, Farrage JR, Kim JS, Taylor GD. Skeletal effects to the maxilla after rapid maxillary expansion assessed with cone-beam computed tomography. Am J Orthod Dentofacial Orthop. 2008 Jul;134(1):8-9.

14. Christie $\mathrm{KF}$, Boucher N, Chung $\mathrm{CH}$. Effects of bonded rapid palatal expansion on the transverse dimensions of the maxilla: a conebeam computed tomography study. Am J Orthod Dentofacial Orthop. 2010 Apr;137(4 Suppl):S79-85. 
15. Lin L, Ahn HW, Kim SJ, Moon SC, Kim SH, Nelson G. Tooth-borne vs bone-borne rapid maxillary expanders in late adolescence. Angle Orthod. 2015 Mar;85(2):253-62.

16. Garib DG, Henriques JF, Carvalho PE, Gomes SC. Longitudinal effects of rapid maxillary expansion. Angle Orthod. 2007 May;77(3):442-8.

17. Haas AJ. Rapid expansion of the maxillary dental arch and nasal cavity by opening the midpalatal suture. Angle Orthod. 1961;31(2):73-90.

18. Davis WM, Kronman JH. Anatomical changes induced by splitting of the midpalatal suture. Angle Orthod. 1969 Apr;39(2):126-32.

19. Chung $\mathrm{CH}$, Font B. Skeletal and dental changes in the sagittal, vertical, and transverse dimensions after rapid palatal expansion. Am J Orthod Dentofacial Orthop. 2004 Nov;126(5):569-75.

20. Gautam P, Valiathan A, Adhikari R. Skeletal response to maxillary protraction with and without maxillary expansion: a finite element study. Am J Orthod Dentofacial Orthop. 2009 Jun;135(6):723-8.

21. Baccetti T, McGill JS, Franchi L, McNamara JA Jr, Tollaro I. Skeletal effects of early treatment of Class III malocclusion with maxillary expansion and face-mask therapy. Am J Orthod Dentofacial Orthop. 1998 Mar;113(3):333-43. 
22. Franchi L, Baccetti T, McNamara JA Jr. Shape-coordinate analysis of skeletal changes induced by rapid maxillary expansion and facial mask therapy. Am J Orthod Dentofacial Orthop. 1998 Oct;114(4):418-26.

23. Vaughn GA, Mason B, Moon HB, Turley PK. The effects of maxillary protraction therapy with or without rapid palatal expansion: a prospective, randomized clinical trial. Am J Orthod Dentofacial Orthop. 2005 Sep;128(3):299-309.

24. Cordasco G, Matarese G, Rustico L, Fastuca S, Caprioglio A, Lindauer SJ, et al. Efficacy of orthopedic treatment with protraction facemask on skeletal Class III malocclusion: a systematic review and meta-analysis. Orthod Craniofac Res. 2014 Aug;17(3):133-43.

25. Foersch M, Jacobs C, Wriedt S, Hechtner M, Wehrbein $\mathrm{H}$. Effectiveness of maxillary protraction using facemask with or without maxillary expansion: a systematic review and metaanalysis. Clin Oral Investig. 2015 Jul;19(6):1181-92.

26. Nienkemper M, Wilmes B, Pauls A, Drescher D. Maxillary protraction using a hybrid hyrax-facemask combination. Prog Orthod. 2013 May 20;14(1):5.

27. Wilmes B, Ngan P, Liou EJ, Franchi L, Drescher D. Early class III facemask treatment with the hybrid hyrax and Alt-RAMEC protocol. J Clin Orthod. 2014 Feb;48(2):84-93. 
28. Nienkemper M, Wilmes B, Franchi L, Drescher D. Effectiveness of maxillary protraction using a hybrid hyrax-facemask combination: a controlled clinical study. Angle Orthod. 2015 Sep;85(5):764-70.

29. Ngan P, Wilmes B, Drescher D, Martin C, Weaver B, Gunel E. Comparison of two maxillary protraction protocols: tooth-borne versus bone-anchored protraction facemask treatment. Prog Orthod. 2015;16:26.

30. Kang S, Lee SJ, Ahn SJ, Heo MS, Kim TW. Bone thickness of the palate for orthodontic mini-implant anchorage in adults. Am J Orthod Dentofacial Orthop. 2007 Apr;131(4 Suppl):S74-81.

31. Becker K, Unland J, Wilmes B, Tarraf NE, Drescher D. Is there an ideal insertion angle and position for orthodontic mini-implants in the anterior palate? A CBCT study in humans. Am J Orthod Dentofacial Orthop. 2019 Sep;156(3):345-54.

32. De Clerck HJ, Cornelis MA, Cevidanes LH, Heymann GC, Tulloch CJ. Orthopedic traction of the maxilla with miniplates: a new perspective for treatment of midface deficiency. J Oral Maxillofac Surg. 2009 Oct;67(10):2123-9.

33. Mohamed RN, Basha S, Al-Thomali Y. Maxillary molar distalization with miniscrew-supported appliances in Class II malocclusion: a systematic review. Angle Orthod. 2018 Jul;88(4):494-502. 